\title{
Functional and phylogenetic components in cercarial nervous systems
}

\author{
Tami Bogéa
}

Department of Ecology and Evolutionary Biology, University of Connecticut, Storrs, Connecticut 06269-3043, USA

Key words: cercarial sensory receptors, chaetotaxy, cholinergic network, ultrastructure, site-specificity, taxonspecificity, functional morphology

\begin{abstract}
Studies involving comparisons of taxa that vary in their degree of relatedness may allow the distinction of functional and phylogenetic components in cercarial sensory systems. In this study, cercariae of allocreadiids Bunodera Railliet, 1896 and Crepidostomum Braun, 1900, lecithodendriid Allassogonoporus Olivier, 1938 and opecoelid Allopodocotyle Pritchard, 1966 were compared as regards ultrastructure and chaetotaxy of sensory receptors as well as neuromorphology. Cercariae were treated with acetylthiocholine iodide and silver nitrate and some were processed for scanning and transmission electron microscopy. The types of cercarial sensory receptors differed in the presence of a tegumentary sheath, a dome-like base and a tegumentary collar, number of cilia ( $0,1,2$ or more), cilium length (short, moderately long or long) and tegumentary collar length (low to moderately low, high or very high). Chaetotaxic patterns were consistent at the family level in all taxa studied. Irregular cholinergic nerve networks were identified. The present study indicates that the major categories of cercarial sensory receptors are nonciliated (including sheathed and subtegumentary types) and ciliated (including uncollared and collared types) receptors. It also allows the distinction of functional and phylogenetic components in the sensory systems of the cercariae studied. Functional components were reflected in the numbers of sensory receptors associated with each nerve region and in the ultrastructure and site-specificity of receptor types. Phylogenetic components included taxon-specific chaetotaxic patterns and receptor types.
\end{abstract}

In the past, the investigation of cercarial sensory systems had emphasised the morphology and distribution of receptor types. Ultrastructural studies have revealed the existence of several types of receptors across the larval tegument of Digenea (Halton et al. 1997). These types suggest that different forms are associated with distinct functions. Site-specificity of receptor types also supports this idea in several species (Bogéa and Caira 2001a, b, c). Functional components are more strongly implicated when similar site-specific patterns are found among distant related taxa, particularly in those that share life-cycle strategies.

Sensory receptor types found to be restricted to groups of related species, on the other hand, would suggest that there might be at least some phylogenetic components to these features. Besides, it is clear that the distribution of receptors on the cercarial tegument is phylogenetically based, with chaetotaxic patterns recognised at the family, genus and species levels (Richard 1971, Bayssade-Dufour 1979, Bayssade-Dufour et al. 1993). What remains unclear, however, is whether receptor types and/or distribution patterns of receptor types may be taxon-specific.

Studies involving comparisons among taxa that vary in their degree of relatedness, therefore, emerge as a strategy that may allow distinction between functional and phylogenetic components in cercarial sensory systems. In the present work, the cercarial neuromorphology and the distribution of sensory receptors were compared among species of the order Plagiorchiformes.
Species representing four genera were selected based on a phylogenetic perspective. This allowed comparisons involving: (1) close relatives with very similar transmission modes, (2) distant relatives with similar transmission modes and (3) distant relatives with different transmission modes. Thus, species belonging to confamilial genera Bunodera Railliet, 1896 and Crepidostomum Braun, 1900 (Allocreadiidae) allowed the first set of comparisons. Both taxa are probably sistergenera (Caira 1989) and have free-swimming ophthalmoxiphidiocercariae, with total length varying from 200 to $300 \mu \mathrm{m}$. The second set of comparisons included the two allocreadiids and a species of Allassogonoporus Olivier, 1938 (Lecithodendriidae), which has a freeswimming virgulate xiphidiocercaria of approximately $100 \mu \mathrm{m}$ length. The third set of comparisons involved the above mentioned taxa and a species of Allopodocotyle Pritchard, 1966 (Opecoelidae), which has a nonswimming cotylomicrocercous cercaria of approximately $350 \mu \mathrm{m}$ length.

\section{MATERIALS AND METHODS}

Cercariae of Bunodera sp. and Crepidostomum sp. were obtained from naturally infected fingernail clams Musculium partumeium (Say), Pisidium casertanum (Poli) and Pisidium aequilaterale (Lea) (Bivalvia: Sphaeriidae). Cercariae of Allassogonoporus sp. and Allopodocotyle sp. were obtained from naturally infected freshwater snails Fluminicola virens (Lea) (Gastropoda: Hydrobiidae) and Juga plicifera (Lea) 
(Gastropoda: Pleuroceridae), respectively. Bottom sediment was collected with the aid of dip nets and sieved through $1 / 4$ " mesh aluminium screening. The molluscs were transported to the laboratory in vials containing pond water and screened for cercariae according to standard procedures.

The most actively emerging cercariae were collected and processed as described elsewhere (Bogéa and Caira 2001a). Voucher specimens have been deposited in the Larry R. Penner Parasitology Collection at the University of Connecticut, USA, U.S. National Parasite Collection, USA and in the Instituto Oswaldo Cruz Helminthological Collection at Fundação Oswaldo Cruz, Brazil.

Ultrastructure of the types of sensory receptors, chaetotaxy, site-specific patterns and nerve network arrangements were previously described in detail for the cercariae of all taxa studied (Bogéa and Caira 2001a, b, c). The external ultrastructure of each receptor type found was described based on number of cilia, presence of a tegumentary sheath, a tegumentary dome-like base and a tegumentary collar and on the morphometric parameters cilium length, cilium width, tegumentary collar length and tegumentary collar width. These parameters were statistically compared among similar receptor types found in each species with the Mann-Whitney $U$ test for two independent samples at a level of significance of less than 0.005 . Total number of sensory receptors and numbers of ventral receptors and of receptors located in each nerve region were compared among all species. All comparisons were performed with the SPSS (Base 10.0 for Macintosh) statistical package.

\section{RESULTS}

\section{Ultrastructure}

A great heterogeneity of types of sensory receptors was identified in the cercariae of Bunodera sp., Crepidostomum sp., Allassogonoporus sp. and Allopodocotyle sp. (Fig. 1). The types were distinguished based on gross morphology seen with scanning and transmission electron microscopes and on statistical analyses. The types of receptors differed in number of cilia (e.g., Figs. 1A, 1J-L), presence of a tegumentary collar (e.g., Fig. 1L), a dome-like base (Figs. 1G-H) and a tegumentary sheath (Figs. 1I, 1N).

Collared receptors were abundant. These receptors have a sensory bulb attached to the tegument by septate extracellular junctional complexes, thickened nerve collars, unsheathed cilia with a central pair of microtubules and a basal body (Figs. 1A-B, 1D).

Similar receptor types were distinguished mostly based on cilium and tegumentary collar lengths (Table 1). The types had either low $(0.23 \pm 0.07 \mu \mathrm{m})$ (e.g., Figs. 1D, $1 \mathrm{~J}-\mathrm{K})$, moderately low $(0.29 \pm 0.11 \mu \mathrm{m})($ e.g., Fig. 1C) or high $(0.62 \pm 0.36 \mu \mathrm{m})$ (e.g., Figs. 1A, 1L) tegumentary collars with short $(1.02 \pm 0.46 \mu \mathrm{m})$ (e.g., Figs. 1A-B), moderately long $(3.12 \pm 1.53 \mu \mathrm{m})$ (e.g., Fig. 1C) or long $(4.73 \pm 1.90 \mu \mathrm{m})$ (e.g., Figs. 1D, 1J-L) cilia.

The ultrastructural investigation of the cercarial sensory receptors in the present taxa revealed that some types were restricted to certain species. Thus, types DI
(Fig. 1G) and DII (Fig. 1H) were restricted to Bunodera sp. whereas types NI (Fig. 1E) and NII (Fig. 1F) occurred in Crepidostomum sp. Types MI (Fig. 1K), MII (Fig. 1L), SI (Fig. 1I), SII (Fig. 1N) and St (Fig. 1M) were found in Allopodocotyle sp.

\section{Basic chaetotaxic and site-specific patterns}

The basic chaetotaxic maps of the four species were investigated in detail. Approximately 170, 163, 178 and 172 cercarial sensory receptors were found on the tegument of Bunodera sp., Crepidostomum sp., Allassogonoporus sp. and Allopodocotyle sp., respectively. Allassogonoporus sp., thus, exhibited more sensory receptors than the other species (Table 2). The numbers of ventral receptors were similar $65.9 \%$ in Bunodera sp., $63.8 \%$ in Crepidostomum sp., $60.7 \%$ in Allassogonoporus sp. and $64.0 \%$ in Allopodocotyle sp.).

Groups of sensory receptors were associated with the nerve regions. Most receptors occurred on the cephalic region (47.65\% in Bunodera sp., $46.63 \%$ in Crepidostomum sp., 49.44\% in Allassogonoporus sp. and $45.35 \%$ in Allopodocotyle sp.). The numbers of posterior receptors were similar among all taxa (Table 2). Bunodera sp. and Crepidostomum sp. presented similar numbers of receptors in each nerve region. Allassogonoporus sp. exhibited more cephalic and anterior receptors and less ventral sucker receptors whereas Allopodocotyle sp. showed more caudal receptors than the other taxa (Table 2).

Fig. 2 illustrates the distribution of the types of sensory receptors throughout the nerve regions in all taxa studied. Type UI was mainly observed around the oral opening whereas type UII was commonly found on the ventral surface of the cercarial body. Type UIII was observed on the body as well as on the cephalic region. Type UIV tended to occur on the dorsal surface of the body.

Some types of sensory receptors were restricted to specific sites within a species (Fig. 2). In Bunodera sp., types DI and DII were concentrated on the dorsal surface of the body and on the tail, and on the lateral surface of the body, respectively (Fig. 2A). Types NI and NII were found only on the tail of Crepidostomum $\mathrm{sp}$. whereas type Bi was restricted to its oral opening (Fig. 2B). Allopodocotyle sp. exhibited three pairs of receptor type SI, each on the cephalic, anterior, and posterior regions. In addition, types MI and MII were found on the ventral surface of the cephalic region (Fig. 2D).

Similar site-specific patterns of cercarial sensory receptors were observed among the species studied (Figs. 2A-D). For instance, high-collared receptors with a short cilium were mainly observed around the oral opening. Low-collared sensory receptors with a moderately long cilium were observed on the cercarial body as well as on the cephalic region in Bunodera sp., Crepidostomum sp. and Allassogonoporus sp. Low-collared receptors with a short cilium were commonly found on 

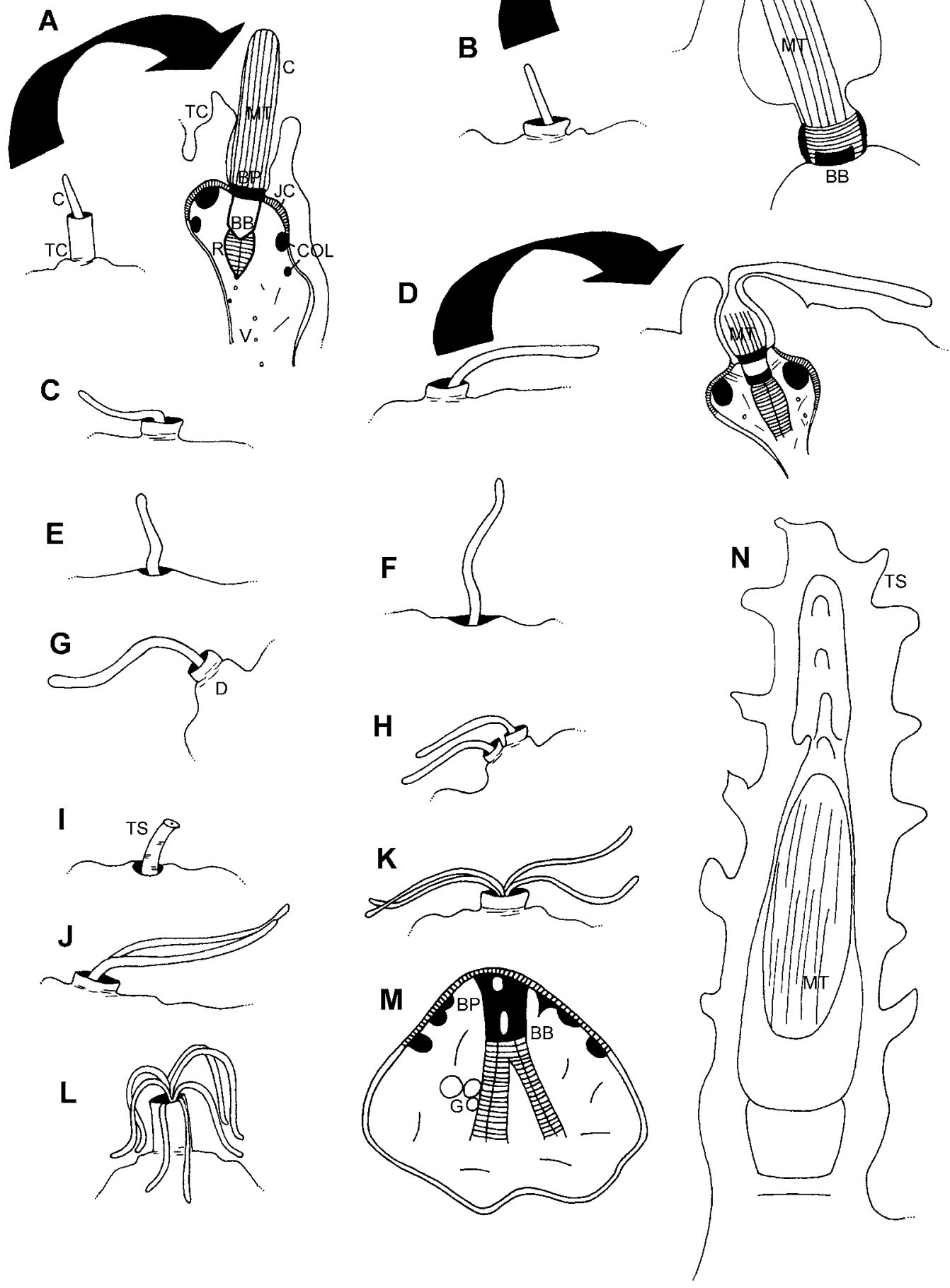

Fig. 1. Types of sensory receptors in cercariae of Bunodera sp., Crepidostomum sp., Allassogonoporus sp. and Allopodocotyle sp. as seen with scanning electron microscopy (SEM). Insets show internal ultrastructure as seen with transmission electron microscopy (TEM). A. Type UI. B. Type UII. C. Type UIII. D. Type UIV. E. Type NI. F. Type NII. G. Type DI. H. Type DII. I. Type SI. J. Type Bi. K. Type MI. L. Type MII. M. Type St as seen with TEM. N. Type SII as seen with TEM. BB - basal body; BP - basal plate; C - cilium; COL - thickening of nerve collar; D - dome-like base; G - granules; JC - extracellular junctional complex; MT - microtubules; TC - tegumentary collar; TS - tegumentary sheath; R - ciliary rootlet; V - vesicles. 


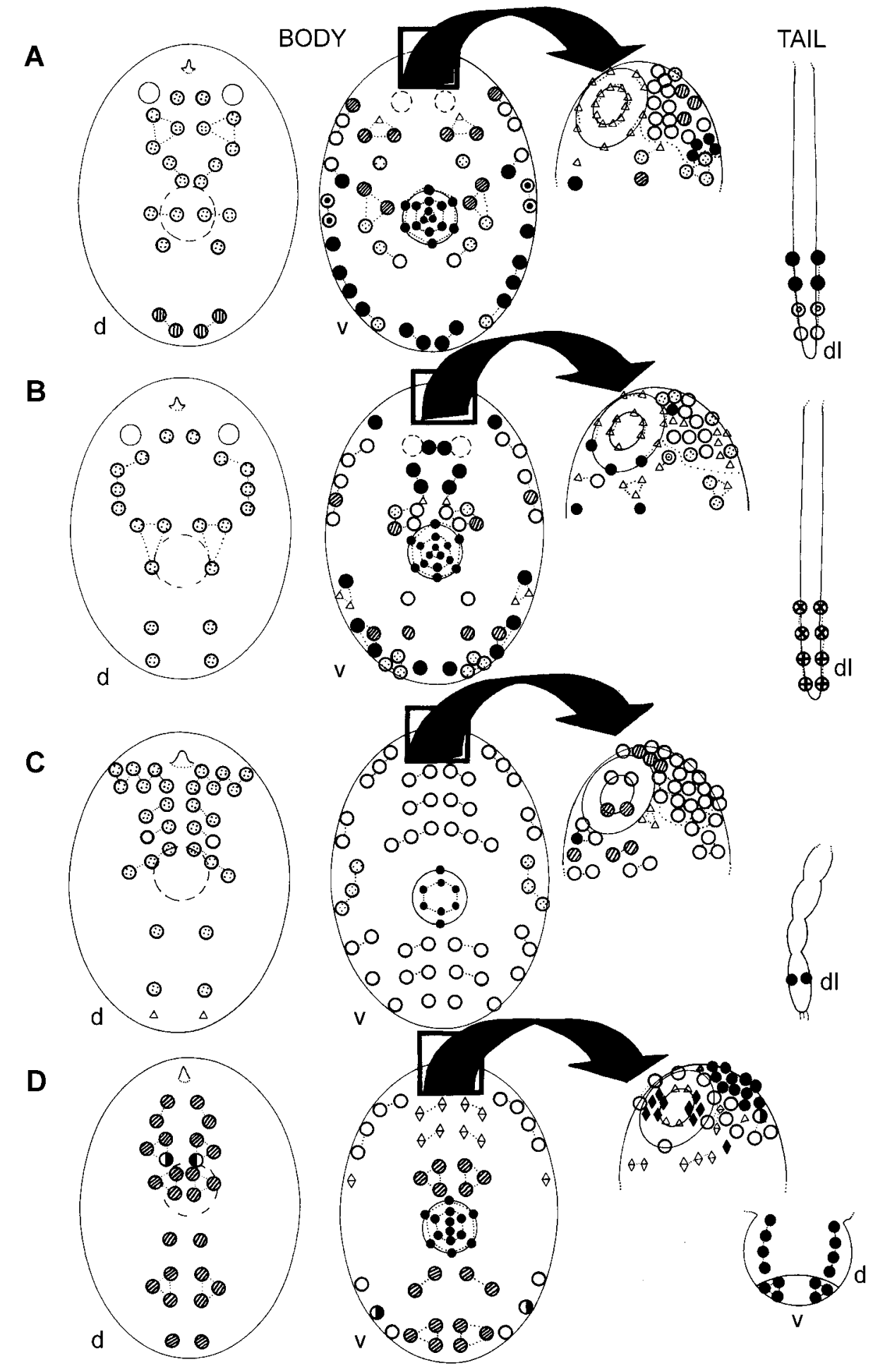

Fig. 2. Sensory receptors in cercariae of Bunodera sp., Crepidostomum sp., Allassogonoporus sp. and Allopodocotyle sp. identified using acetylthiocholine method for cholinesterase, silver nitrate impregnation and scanning electron microscopy. Dorsal and ventral views of cercarial body and tail are presented for each species. Insets show receptors of cephalic region. A. Bunodera sp. B. Crepidostomum sp. C. Allassogonoporus sp. D. Allopodocotyle sp. d - dorsal view; dl - dorsolateral view; v - ventral view. Codes refer to sensory receptor types shown in Fig. $1 . \Delta$ - type UI; O - type UII; $\mathbb{D}$ - type UIII;

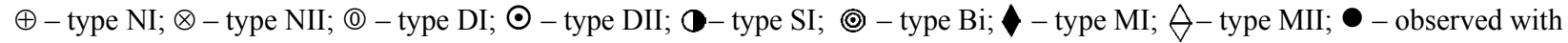
light microscopy. 
Table 1. Comparisons of sensory receptor types among cercariae of Bunodera sp., Crepidostomum sp., Allassogonoporus sp. and Allopodocotyle sp. as indicated by the Mann-Whitney $U$ test. Significant differences $(\mathrm{p}<0.005)$ are shown in bold. CL - cilium length; CW - cilium width; TCL - tegumentary collar length; TCW - tegumentary collar width.

\begin{tabular}{|c|c|c|c|c|}
\hline Species & CL & $\mathrm{CW}$ & TCL & TCW \\
\hline \multirow{6}{*}{ Bunodera sp. } & $\mathrm{UI}=\mathrm{UII}$ & $\mathrm{UI}=\mathrm{UII}$ & $\mathbf{U I}>\mathbf{U I I}$ & $\mathrm{UI}=\mathrm{UII}$ \\
\hline & $\mathbf{U I}<\mathbf{U I I I}$ & $\mathrm{UI}=\mathrm{UIII}$ & UI > UIII & UI = UIII \\
\hline & $\mathbf{U I}<\mathbf{U I V}$ & $\mathrm{UI}=\mathrm{UIV}$ & $\mathbf{U I}>\mathbf{U I V}$ & $\mathrm{UI}=\mathrm{UIV}$ \\
\hline & UII $<$ UIII & UII = UIII & UII = UIII & UII = UIII \\
\hline & UII $<$ UIV & $\mathrm{UII}=\mathrm{UIV}$ & $\mathrm{UII}=\mathrm{UIV}$ & $\mathrm{UII}=\mathrm{UIV}$ \\
\hline & UIII $<$ UIV & UIII > UIV & $\mathrm{UIII}=\mathrm{UIV}$ & $\mathrm{UIII}=\mathrm{UIV}$ \\
\hline \multirow{6}{*}{ Crepidostomum sp. } & UI $<$ UII & $\mathrm{UI}=\mathrm{UII}$ & $\mathbf{U I}>\mathbf{U I I}$ & $\mathbf{U I}<\mathbf{U I I}$ \\
\hline & UI $<$ UIII & $\mathrm{UI}=\mathrm{UIII}$ & UI > UIII & UI $<$ UIII \\
\hline & $\mathbf{U I}<\mathbf{U I V}$ & $\mathbf{U I}<\mathbf{U I V}$ & $\mathbf{U I}>\mathbf{U I V}$ & $\mathbf{U I}<\mathbf{U I V}$ \\
\hline & UII $<$ UIII & UII = UIII & UII > UIII & UII = UIII \\
\hline & UII $<$ UIV & UII $<$ UIV & $\mathrm{UII}=\mathrm{UIV}$ & $\mathrm{UII}=\mathrm{UIV}$ \\
\hline & UIII $<$ UIV & UIII $<$ UIV & UIII $<$ UIV & UIII $<$ UIV \\
\hline \multirow{6}{*}{ Allassogonoporus sp. } & $\mathrm{UI}=\mathrm{UII}$ & $\mathrm{UI}=\mathrm{UII}$ & UI $>$ UII & $\mathbf{U I}<\mathbf{U I I}$ \\
\hline & UI < UIII & UI = UIII & UI > UIII & UI = UIII \\
\hline & $\mathbf{U I}<\mathbf{U I V}$ & $\mathrm{UI}=\mathrm{UIV}$ & UI > UIV & $\mathbf{U I}<\mathbf{U I V}$ \\
\hline & UII $<$ UIII & UII = UIII & UII = UIII & UII > UIII \\
\hline & UII $<$ UIV & $\mathrm{UII}=\mathrm{UIV}$ & $\mathrm{UII}=\mathrm{UIV}$ & $\mathrm{UII}=\mathrm{UIV}$ \\
\hline & UIII = UIV & $\mathrm{UIII}=\mathrm{UIV}$ & UIII = UIV & UIII $<$ UIV \\
\hline \multirow{6}{*}{ Allopodocotyle sp. } & $\mathbf{U I}=\mathbf{U I I}$ & $\mathrm{UI}=\mathrm{UII}$ & $\mathbf{U I}>\mathbf{U I I}$ & $\mathrm{UI}=\mathrm{UII}$ \\
\hline & $\mathbf{U I}<\mathbf{M I}$ & $\mathbf{U I}>\mathbf{M I}$ & $\mathbf{U I}>\mathbf{M I}$ & $\mathrm{UI}=\mathrm{MI}$ \\
\hline & $\mathbf{U I}<\mathbf{M I I}$ & UI $>$ MII & $\mathbf{U I}=\mathbf{M I I}$ & $\mathrm{UI}=\mathrm{MII}$ \\
\hline & $\mathbf{U I I}<\mathbf{M I}$ & $\mathbf{U I I}>\mathbf{M I}$ & UII $>$ MI & $\mathrm{UII}=\mathrm{MI}$ \\
\hline & UII < MII & UII > MII & UII $<$ MII & $\mathrm{UII}=\mathrm{MII}$ \\
\hline & MI $>$ MII & $\mathrm{MI}=\mathrm{MII}$ & MI $<$ MII & $\mathrm{MI}=\mathrm{MII}$ \\
\hline
\end{tabular}

Table 2. Comparisons in distribution of sensory receptors among cercariae of Bunodera sp., Crepidostomum sp., Allassogonoporus sp. and Allopodocotyle sp. as indicated by the Mann-Whitney $U$ test. Significant differences $(\mathrm{p}<0.005)$ are shown in bold. $\mathrm{T}$ - total number of sensory receptors; $\mathrm{V}$ - number of ventral receptors; $\mathrm{C}$ - number of cephalic receptors; $\mathrm{A}$ - number of anterior receptors; $\mathrm{S}$ - number of ventral sucker receptors; $\mathrm{P}$ - number of posterior receptors; $\mathrm{U}$ - number of caudal receptors.

\begin{tabular}{|l|c|c|c|c|c|c|c|}
\hline Comparison & $\mathrm{T}$ & $\mathrm{V}$ & $\mathrm{C}$ & $\mathrm{A}$ & $\mathrm{S}$ & $\mathrm{P}$ & $\mathrm{U}$ \\
\hline Bunodera $\mathrm{sp}$. & $\mathbf{1 7 0}$ & 112 & $\mathbf{8 1}$ & $\mathbf{4 2}$ & $\mathbf{1 5}$ & 24 & 8 \\
$\times$ & $\neq$ & $=$ & $\neq$ & $\neq$ & $\neq$ & $=$ & $=$ \\
Allassogonoporus sp. & $\mathbf{1 7 8}$ & 108 & $\mathbf{8 8}$ & $\mathbf{5 6}$ & $\mathbf{8}$ & 24 & 2 \\
\hline Bunodera $\mathrm{sp}$. & 170 & 112 & 81 & 42 & 15 & 24 & $\mathbf{8}$ \\
$\times$ & $=$ & $=$ & $=$ & $=$ & $=$ & $=$ & $\neq$ \\
Allopodocotyle sp. & 172 & 110 & 78 & 40 & 14 & 26 & $\mathbf{1 4}$ \\
\hline Bunodera sp. & 170 & 112 & 81 & 42 & 15 & 24 & 8 \\
$\times$ & $=$ & $=$ & $=$ & $=$ & $=$ & $=$ & $=$ \\
Crepidostomum $\mathrm{sp}$. & 163 & 104 & 76 & 40 & 15 & 24 & 8 \\
\hline Crepidostomum $\mathrm{sp}$. & $\mathbf{1 6 3}$ & 104 & $\mathbf{7 6}$ & $\mathbf{4 0}$ & $\mathbf{1 5}$ & 24 & 8 \\
$\times$ & $\neq$ & $=$ & $\neq$ & $\neq$ & $\neq$ & $=$ & $=$ \\
Allassogonoporus $\mathrm{sp}$. & $\mathbf{1 7 8}$ & 108 & $\mathbf{8 8}$ & $\mathbf{5 6}$ & $\mathbf{8}$ & 24 & 2 \\
\hline Crepidostomum $\mathrm{sp}$. & 163 & 104 & 76 & 40 & 15 & 24 & $\mathbf{8}$ \\
$\times$ & $=$ & $=$ & $=$ & $=$ & $=$ & $=$ & $\neq$ \\
Allopodocotyle $\mathrm{sp}$. & 172 & 110 & 78 & 40 & 14 & 26 & $\mathbf{1 4}$ \\
\hline Allassogonoporus $\mathrm{sp}$. & $\mathbf{1 7 8}$ & 108 & $\mathbf{8 8}$ & $\mathbf{5 6}$ & $\mathbf{8}$ & 24 & $\mathbf{2}$ \\
$\times$ & $\neq$ & $=$ & $\neq$ & $\neq$ & $\neq$ & $=$ & $\neq$ \\
Allopodocotyle sp. & $\mathbf{1 7 2}$ & 110 & $\mathbf{7 8}$ & $\mathbf{4 0}$ & $\mathbf{1 4}$ & 26 & $\mathbf{1 4}$ \\
\hline
\end{tabular}

the ventral surface of the cercarial body whereas those with a long cilium tend to occur mainly on the dorsal surface in all species.

\section{Nerve network}

The basic arrangements of the nerve networks of the cercariae of Bunodera sp., Crepidostomum sp., Allasso- gonoporus sp. and Allopodocotyle sp. are shown in Fig. 3 . They were found to consist of a bilobed cerebral ganglion located at the pharynx level (Figs. 3A-C) or of a large ramified cerebral ganglion located above the pharynx (Fig. 3D). Three pairs of lateral, dorsal and ventral longitudinal nerve cords extended anteriorly and posteriorly from the cerebral ganglion. 


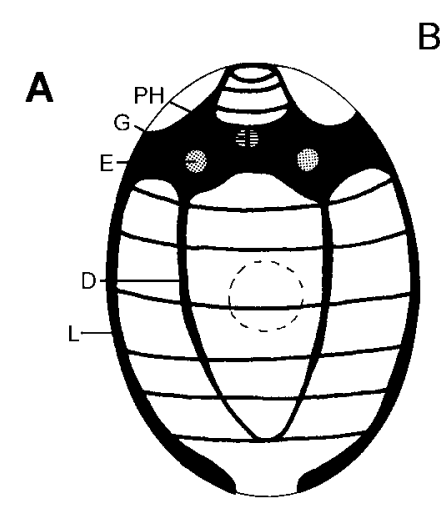

BODY

B
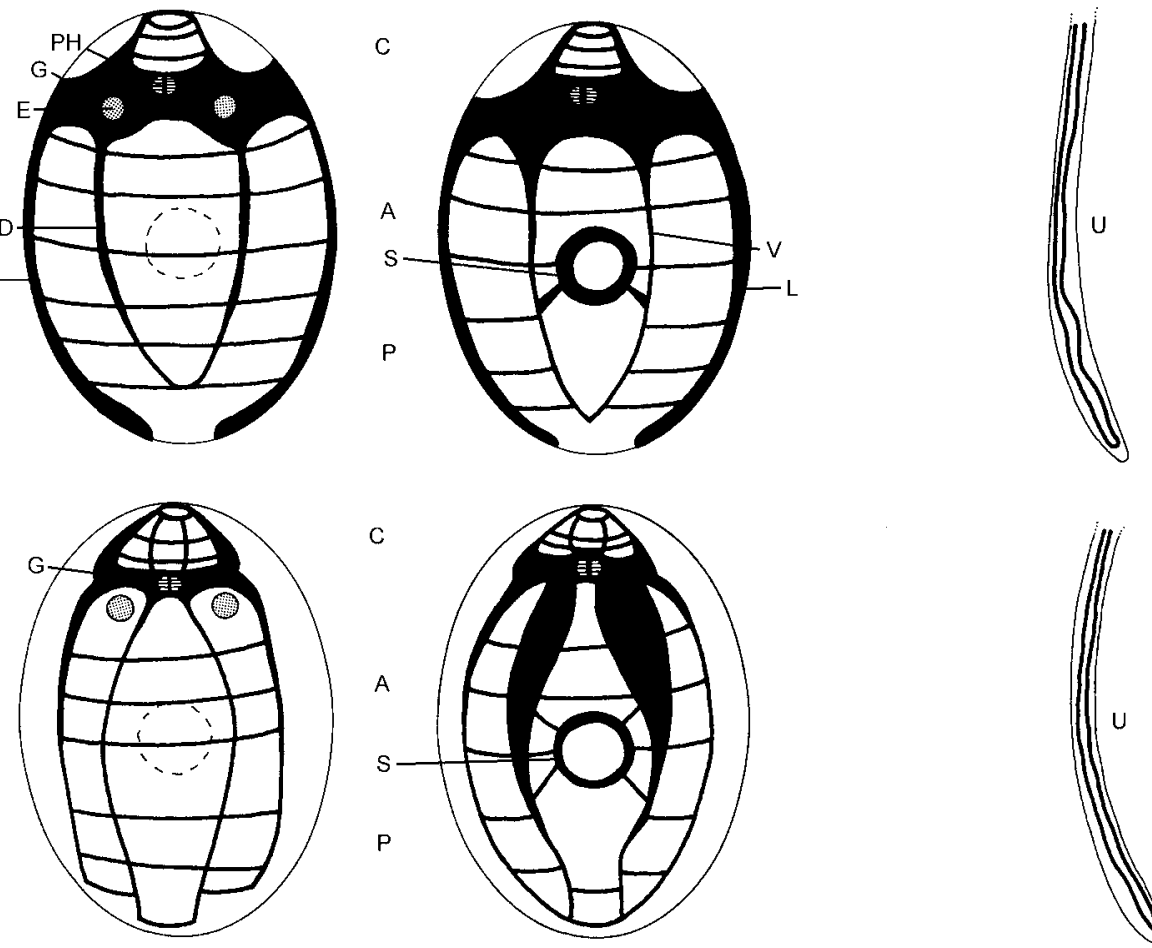

C
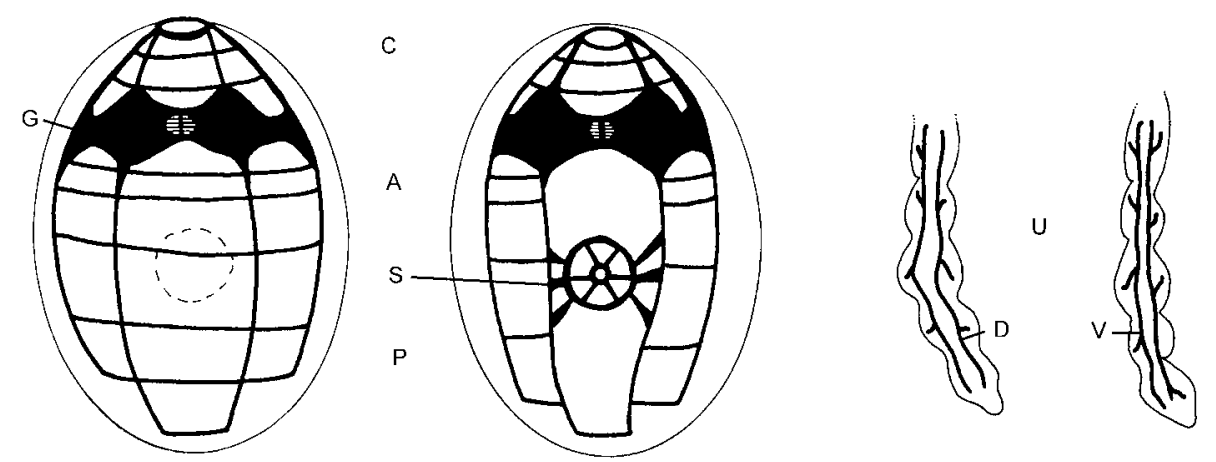

D
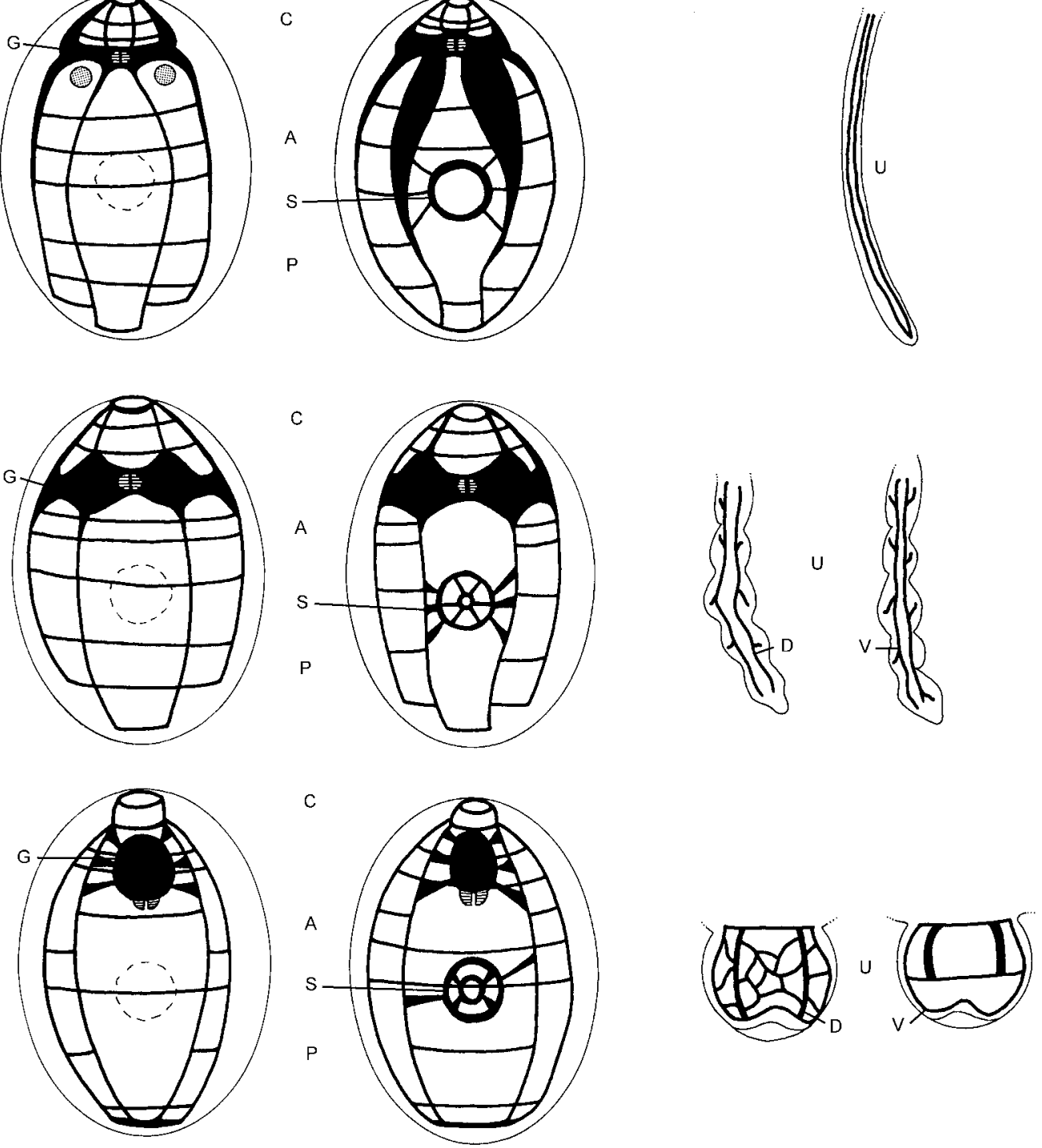

Fig. 3. Arrangement of major transverse commissures and nerve cords in cercariae of Bunodera sp., Crepidostomum sp., Allassogonoporus sp. and Allopodocotyle sp. as seen with acetylthiocholine method for cholinesterase. Dorsal and ventral views of cercarial body and tail are presented for each species. A. Bunodera sp. B. Crepidostomum sp. C. Allassogonoporus sp. D. Allopodocotyle sp. A - anterior transverse commissures; C - cephalic transverse commissures; D - dorsal nerve cord; E eyespot; $\mathrm{G}$ - cerebral ganglion; $\mathrm{L}$ - lateral nerve cord; $\mathrm{PH}$ - pharynx; P - posterior transverse commissures; $\mathrm{S}$ - ventral sucker nerve region; $\mathrm{U}$ - caudal nerve cord; $\mathrm{V}$ - ventral nerve cord. 
Three cephalic, three anterior and three posterior transverse commissures were identified in all species. In Allopodocotyle sp., a fourth cephalic transverse commissure was identified (Fig. 3D). Some of the commissures did not surround the cercaria entirely. All species exhibited distinctive rings on the ventral sucker, with Allassogonoporus sp. and Allopodocotyle sp. presenting many innervations in this region. Fine connections branching from the ventral longitudinal nerve cords to the oral and ventral suckers were also observed.

Two ventral longitudinal nerve cords were observed in the tail of the four species one along each of the lateral margins of the tail. In the cercariae of Allassogonoporus sp. and Allopodocotyle sp., the two cords were observed branching into fine ramifications (Figs. $3 \mathrm{C}-\mathrm{D})$. A complex nerve network was observed on the tail of Allopodocotyle sp.

\section{DISCUSSION}

\section{Functional components}

Different types of sensory receptors were identified in the cercariae of Bunodera sp., Crepidostomum sp., Allassogonoporus sp. and Allopodocotyle sp. They are grouped in the following major categories:

1.0 - Nonciliated receptors, with no cilia emerging through the tegument:

1.1 Sheathed receptors (types SI and SII): with microtubules surrounded by a short or long, thick, stiff tegumentary sheath.

1.2 Subtegumentary receptors (type $\mathrm{St}$ ): with a sensory bulb attached to the tegument by septate extracellular junctional complexes, two pairs of thickened nerve collars, a distinctive bifurcated ciliary rootlet, a basal plate and a basal body.

2.0 - Ciliated receptors, with one or more cilia:

2.1 Uncollared receptors (types NI and NII): with no tegumentary collar and moderately long or long unsheathed cilia.

2.2 Collared receptors, with a tegumentary collar:

2.2.1 Low-collared receptors (types DI, DII, UII, UIII, UIV, MI and Bi): with a low to moderately low tegumentary collar, with a tegumentary domelike base or not, short, moderately long or long unsheathed cilia, a central pair of microtubules, a basal body, a sensory bulb attached to the tegument by septate extracellular junctional complexes and two pairs of thickened nerve collars.

2.2.2 High-collared receptors (types UI and MII): with a moderately low to very high tegumentary collar, short or long unsheathed cilia, a central pair of microtubules, a basal body, a sensory bulb attached to the tegument by septate extracellular junctional complexes and two pairs of thickened nerve collars.

Some of these types are similar to types previously described (Køie 1981, Žd'árská 1992, Czubaj and Nie- wiadomska 1996, Niewiadomska and Czubaj 1996, Moravec 2002).

The collared receptor type is abundantly found. Its ultrastructure is similar among the taxa studied, suggesting that these receptors likely respond to the same sensory modality. They are possibly associated with mechanoreception (Bogéa and Caira 2001a).

Similar site-specific patterns of cercarial sensory receptors were observed within a species and among the species studied. Thus, "domed" receptors of Bunodera sp., biciliated receptors of Crepidostomum sp., and highcollared receptors with multiple cilia of Allopodocotyle sp. occurred in particular sites of the cercarial body. Also, the distribution of short- and long-ciliated receptors with low tegumentary collars on the ventral and dorsal surfaces of the cercarial body, respectively, may reflect their different functions.

Functional components were also investigated in the numbers of sensory receptors on each cercarial surface and in the numbers of receptors associated with each nerve region in the four species studied. Independent of their degree of relatedness, all species studied exhibit receptors concentrated on the ventral surface of the cephalic region (Table 2). This similarity may be related to the importance of the oral sucker region in the strategies for host finding in these species (Knight and Pratt 1955, Cannon 1971).

The numbers of cercarial sensory receptors associated with each nerve region, on the other hand, differ in all species (Table 2). Besides, they differ among the species, with Allassogonoporus sp. exhibiting more cephalic and anterior receptors and less ventral sucker receptors and Allopodocotyle sp. presenting more caudal receptors than the other taxa. These results support the idea that sensory receptors tend to accumulate in regions that are actively involved in host recognition and penetration (Richard 1971, Bayssade-Dufour 1979, Haas and Haberl 1997). These regions may vary according to the type of cercaria and its transmission mode.

\section{Phylogenetic components}

The present study extends the chaetotaxic investigations to Bunodera sp., Crepidostomum sp., Allassogonoporus sp. and Allopodocotyle sp. Different maps obtained for each species suggest taxon-specific patterns (Fig. 2). These maps also confirm the diagnostic characters previously established for the families Allocreadiidae, Lecithodendriidae and Opecoelidae (Richard 1971, Bayssade-Dufour 1979, Bayssade-Dufour et al. 1993).

Some of the types of sensory receptors detected seem species-specific. For example, "domed" receptors were only observed in the cercaria of Bunodera sp. (Fig. 2A). Uncollared receptors with a short or a moderately long cilium and low-collared receptors with two long cilia were restricted to the cercaria of Crepidostomum sp. (Fig. 2B). Collared receptors with multiple cilia and sheathed and subtegumentary receptors were exclusively found in Allopodocotyle sp. (Fig. 2D). Studies on 
sensory receptors in cercariae of different families are particularly encouraged to verify whether taxon-specific types could be used as synapomorphies for the taxa involved.

The total numbers of sensory receptors and the numbers of ventral receptors are rather uniform among the species studied. The free-swimming cercariae of $\mathrm{Bu}$ nodera sp. and Crepidostomum sp. and the non-swimming cercaria of Allopodocotyle sp. exhibit similar total numbers of sensory receptors whereas the free-swimming cercaria of Allassogonoporus sp. has slightly more receptors than the other species (Table 2). The numbers of ventral receptors, however, are similar among all species. Because the total length of these cercariae varies considerably, the total number of sensory receptors and the number of ventral receptors appear relatively independent of cercarial size. Further investigations are required to determine whether the number of ventral receptors reflects an optimal design associated with constraints of a free-living mode of existence.

The numbers of cercarial sensory receptors associated with each nerve region seem to be more similar between closely related cercariae than among those more distantly related. The allocreadiid cercariae of $\mathrm{Bu}$ nodera sp. and Crepidostomum sp. exhibit more similar numbers of receptors between each other than in relation to those detected in lecithodendriid Allassogonoporus sp. and opecoelid Allopodocotyle sp. (Table 2). These results suggest that there are phylogenetic correlates involved in the distribution of cercarial sensory receptors throughout each nerve region.

Cholinergic components are demonstrated in the cerebral ganglion, nerve cords and transverse commissures of the cercariae studied. They are particularly associated with the innervations of cercarial sensory receptors (Bogéa T. and Brito-Gitirana L., UFRJ, Rio de Janeiro, Brazil, unpubl.). Similar arrangements have been determined in cholinergic nerve networks of other cercariae (Nezlin et al. 1992).

The investigation of cholinergic nerve networks has been useful to identify evolutionary trends in the organisation of platyhelminth nervous systems. It has been suggested that the general trend would involve an increased cephalisation followed by a reduction of nerves in the posterior body (Shishov 1991). Different platyhelminth orthogons had been considered homologous, being derived from the cord-type of Acoela and Catenulida which is characterised by a meshwork of nerve fibres (Kotikova 1991 after Reuter and Gustafsson 1995). The present cercarial orthogons are classified as irregular because many transverse commissures do not surround the cercaria entirely. This arrangement would have derived directly from the cord-type.

Acknowledgements. I am particularly indebted to Dr. J.N. Caira for invaluable support and for comments on an earlier version of this paper. I thank all individuals that helped in the collection of molluscs. I am grateful to Dr. K. Tiekotter for his assistance as well as for providing me with infected snails. Special thanks go to J. Romanow for expert assistance and to Drs. M. Cantino, C. Henry, E. Joikinen, L. Khairallah and C. Schaefer for good advice. I am indebted to Dr. L. BritoGitirana for comments on a version of the present paper and for granting access to laboratory facilities. This investigation was supported by Doctoral fellowships of the University of Connecticut, USA, and the "Conselho Nacional de Desenvolvimento Científico e Tecnológico" (CNPq), Brazil, (no. 200142/94-1) and by Research grants of CNPq (nos. 300509/ 00-6 and 150021/03-8) awarded to T.B.

\section{REFERENCES}

BAYSSADE-DUFOUR C. 1979: L'appareil sénsoriel des cercaries et la systématique des trématodes digenétiques. Mem. Mus. Natl. Hist. Nat., Paris, Série A 113: 1-81.

BAYSSADE-DUFOUR C., HUGOT J.-P., ALBARET J.-L. 1993: Analyse phénétique des Microphalloidea (Trematoda) d'après la chétotaxie des cercaires. Syst. Parasitol. 25: $1-24$

BOGÉA T., CAIRA J.N. 2001a: Ultrastructure and chaetotaxy of sensory receptors in the cercariae of Crepidostomum sp. Braun, 1900 and Bunodera sp. Railliet, 1896 (Digenea: Allocreadiidae). J. Parasitol. 87: 273-286.

BOGÉA T., CAIRA J.N. 2001b: Ultrastructure and chaetotaxy of sensory receptors in the cercariae of Allopodocotyle sp. Pritchard, 1966 (Digenea: Opecoelidae). Mem. Inst. Oswaldo Cruz 96: 205-214

BOGÉA T., CAIRA J.N. 2001c: Ultrastructure and chaetotaxy of sensory receptors in the cercariae of Allassogonoporus sp. Olivier, 1938 (Digenea: Lecithodendriidae). Syst. Parasitol. 50: 1-11.

CAIRA J.N. 1989: A revision of the North American papillose Allocreadiidae with independent cladistic analyses of larval and adult forms. Bull. Univ. Nebr. State Mus. 11: 158.

CANNON L.R.G. 1971: The life cycles of Bunodera sacculata and B. luciopercae (Trematoda: Allocreadiidae) from Algonquin Park. Can. J. Zool. 49: 1417-1429.

CZUBAJ A., NIEWIADOMSKA K. 1996: Ultrastructure of sensory endings in Diplostomum pseudospathaceum Niewiadomska, 1984 cercariae (Digenea: Diplostomidae). Int. J. Parasitol. 26: 1217-1225.

HAAS W., HABERL B. 1997: Host recognition by trematode miracidia and cercariae. In: B. Fried and T. K. Graczyk (Eds.), Advances in Trematode Biology. CRC Press, Boca Raton, pp. 197-227.

HALTON D.W., MAULE A.G., SHAW C. 1997: Trematode neurobiology. In: B. Fried and T.K. Graczyk (Eds.), Advances in Trematode Biology. CRC Press, Boca Raton, pp. 345-382.

KNIGHT R.A., PRATT I. 1955: The life histories of Allassogonoporus vespertilionis Macy and Acanthatrium oregonense Macy (Trematoda: Lecithodendriidae). J. Parasitol. 41: 248-255. 
KØIE M. 1981: On the morphology and life-history of Podocotyle reflexa (Creplin, 1825) Odhner, 1905, and a comparison of its developmental stages with those of $P$. atomon (Rudolphi, 1802) Odhner, 1905 (Trematoda, Opecoelidae). Ophelia 20: 17-43.

MORAVEC F. 2002: External morphological differences between Crepidostomum farionis and Crepidostomum metoecus (Trematoda: Allocreadiidae), parasites of salmonids, as revealed by SEM. Folia Parasitol. 49: 211-217.

NEZLIN L.P., RYBAKOV A.V., KONTRIMAVICHYUTE D.V. 1992: Histochemical study of the nerve system of Podocotyle atomon cercariae (Trematoda: Opecoelidae). Parazitologiya 26: 115-121. (In Russian.)

NIEWIADOMSKA K., CZUBAJ A. 1996: Sensory endings in Diplostomum pseudospathaceum Niewiadomska, 1984 cercariae (Digenea, Diplostomidae). Acta Parasitol. 41: $20-25$.

Received 13 April 2004
REUTER M., GUSTAFSSON M.K.S. 1995: The flatworm nervous system: pattern and phylogeny. In: O. Breidbach and W. Kutsch (Eds.), The Nervous Systems of Invertebrates: an Evolutionary and Comparative Approach. Birkhauser Verlag, Basel, pp. 25-59.

RICHARD J. 1971: La chétotaxie des cercaires: valeur systématique et phylétique. Mem. Mus. Natl. Hist. Nat., Paris, Série A 67: 1-179.

SHISHOV B.A. 1991: Aminergic elements in the nervous system of helminths. In: D.A. Sakharov and W. Winlow (Eds.), Simpler Nervous Systems. Manchester University Press, Manchester, pp. 113-152.

ŽĎÁRSKÁ Z. 1992: Transmission electron microscopy of sensory receptors of Echinostoma revolutum (Froelich, 1802) cercaria (Digenea: Echinostomatidae). Parasitol. Res. 78: 598-606.

Accepted 28 July 2004 